\title{
Study on Inflammation and the Nervous system of Ethanol extract of Jatropha Curcas seed
}

\author{
Zambrano-Huailla Alexander ${ }^{1,2}$, Zambrano-Huailla Rommel ${ }^{1,2}$, Goicochea-Lugo Sergio ${ }^{1,2}$, Zavala-Flores Ernesto ${ }^{1,2}$, García-Berrocal Jorge ${ }^{1}$, \\ Chau-Saravia Angel ${ }^{1}$, Pante-Medina Carlos ${ }^{2}$, Salazar-Granara Alberto ${ }^{1,2}$ \\ 'Centro de Investigación de Medicina Tradicional y Farmacología (CIMTFAR) de la Facultad de Medicina Humana de la Universidad de San Martin de Porres. \\ (FMH-USMP), PERU. El Corregidor Avenue 1531, La Molina, Lima12, PERU. \\ ${ }^{2}$ Sociedad Científica de Estudiantes de Medicina de la Universidad San Martin de Porres (SOCIEM-USMP), PERU.
}

\begin{abstract}
Introduction: Jatropha curcas L. seeds are used in traditional medicine to treat a variety of diseases or conditions. The aim of this study is to evaluate effects on inflammation and the nervous system of ethanol extract of J. curcas seeds. Materials and methods: It was used 64 mice divided in 8 groups; respectively, 4 groups received $400,600,800$ and $1000 \mathrm{mg} / \mathrm{kg}$ of ethanol extract of $\mathrm{J}$. curcas seed; and the rest intake Diclofenac, Diazepam, Caffeine and a control group not received any substance. The effects on inflammation was evaluated by Carrageenan-Induced paw oedema test and by Paw skin temperature. Neurological symptoms of toxicity were evaluated using the Irwin test. For the analysis of quantitative variables were used the following tests: one-way ANOVA, Tukey, Shapiro-Wilk and Pearson correlation; for qualitative variables Chi square was used. Results: According to the paw oedema, it was showed a trend on an inflammatory effect of the seeds of $J$. curcas; this activity was statistically significant in doses of $1000 \mathrm{mg} / \mathrm{kg}$. Also, the skin temperature measurements out-
\end{abstract}

comes reveal a positive dose response manner. Regard to neurological manifestations, Straub tail was founded in doses of $400 \mathrm{mg} / \mathrm{kg}$. Stereotypies were founded in doses of $400,600,800$ and $1000 \mathrm{mg} / \mathrm{kg}$ throughout the evaluation. Conclusion: J. curcas seeds were showed an inflammatory effect. In addition, effects on the nervous system were founded as stereotypes and Straub tail.

Key words: Jatropha curcas, Seeds, Inflammation, Carrageenan, Nervous System.

Corresponding author: Salazar-Granara Alberto, El Corregidor avenue 1531, Las Viñas, La Molina12, Lima-PERU. Facultad de Medicina Humana de la Universidad de San Martin de Porres.

Phone: 5113652300; extension 151.

Email: alberto.salazar@gmail.com ó asalazarg@usmp.pe DOI : 10.5530/pj.2016.4.5

\section{INTRODUCTION}

Jatropha curcas (Linnaeus) is a plant which belongs to family Euphorbiaceae and genus Jatropha. This plant is native of America and is widely distributed, is also located in Africa, Asia and Europe where it grows in arid, tropical and sub-tropical environments. Its name derives from the Greek words "Jatros" (doctor) and "trophe" (food) which translates its medicinal traditional use. ${ }^{1}$

Such medicinal use is reported in diverse consumption of different parts of $J$. curcas, some of them through infusions for various conditions such as fever, burn, rheumatism, allergies, diarrhea, intestinal cramping, healing, dysentery, parasitic infections, etc. ${ }^{2,3}$

Thus J. curcas seeds have acquired importance for its extra-medicinal properties $^{4}$ and its use in native communities for some conditions as arthritis, gout, jaundice, convulsions, constipation, diarrhea, fever and inflammation. ${ }^{3,5,6}$

In Peru, this plant is located in departments of Lima, Piura, Cajamarca, San Martin, Cusco, Ucayali and Loreto where its traditional practices were also recognised. ${ }^{3,7,8}$

Preclinical studies have demonstrated the biological activity of the different parts of $J$. curcas, so, antifungal and acaricide activity of seeds; ${ }^{9-13}$ antidiarrheal, anti inflammatory and antimicrobial effect of the root, stem, bark and leaf; ${ }^{3,14-17}$ abortifacient activity of fruit ${ }^{18}$ and activity on the blood coagulation of latex. ${ }^{6}$

These recognized effects of $J$. curcas might be supported by presence of secondary metabolites as alkaloids, flavonoids, esters, lectins, tannins, saponins, terpenoids, lipases, among others. ${ }^{19-23}$

In addition, there are validated methods to evaluate effects on the nervous system and inflammatory activity as Irwin test and Carrageenan- induced paw oedema test, which were used to validate pharmacological effects of some medicinal plants. ${ }^{24-28}$

Considering the increase of interest for the value of this medicinal plant, ${ }^{29}$ this study focused on assessment of effects on inflammation and the nervous system of ethanol extract of J. curcas seeds in escalating doses.

\section{MATERIALS AND METHODS}

\section{Chemical Sample}

Diclofenac ampoules 75 mg/3 mL, code A021143, RS: EG-2537; Lambda Carrageenan 25 g, code 80 K 1334; Caffeine tablet 100 mg, code 1060522, RS: N-24400; Diazepam ampoules $5 \mathrm{mg} / \mathrm{m} \mathrm{l} \times 2 \mathrm{ml}$, code 10950583, RS: NG-3084.

\section{Plant material and extraction}

It was used Jatropha curcas seeds which was collected in the Department of Loreto (Iquitos) under the criteria of the Cerrate method E.1969: ${ }^{30}$

1.- First, the vascular plant was collected at 08:00 hrs

2.- Then, it was put immediately into a field press

3.- After that, it was dried

Berta Loja, who is biologist of The Research Centre of Traditional Medicine and Pharmacology, FMH-USMP, authenticated the taxonomy of the plant. For mark the specimens it was crossover the information with the herbaria of the Universidad Nacional Mayor de San Marcos (USM) and the Missouri Botanical Garden (MO). Finally, it was classified gender and specie as Jatropha curcas according to Peruvian ${ }^{31-33}$ and all continent America, South Africa, and Asia flora references. ${ }^{34-37}$

The extract was prepared from dried and ground seeds of J. curcas, this was macerated in $70 \%$ ethanol for a week, then the mixture was filtered 
and the obtained residue was dried in an oven for a period of 7 days. The dried sample was ground in a mortar to obtain a fine powder which was stored in airtight containers and refrigerated until its experimental use.

\section{Animals and study design}

64 Mus musculus male albino mice were obtained from National Institute of Health (Instituto Nacional de Salud, INS-Bioterio, Chorrillos, Lima-Perú), whose weight average were between 25 and $30 \mathrm{~g}$. Mice were undergone to an acclimatization process in FMH-USMP; they were housed 4 per cage and were maintained at the following conditions: temperature $22^{\circ} \mathrm{C}( \pm 2)$, humidity between 30 and $70 \%, 12 \mathrm{hr}$ light/dark cycles and noise levels less than $70 \mathrm{~dB}$.

Mice were provided with balanced food and water ad libitum and then they were deprived of food $12 \mathrm{hrs}$ before the development of experiment.

Animals were divided in 8 groups of 8 mice each group. 4 experimental groups which orally intake ethanol extracts of $J$. curcas seed in escalating doses of $400,600,800$ and $1000 \mathrm{mg} / \mathrm{kg}$. 4 control groups which three of them received orally caffeine $32 \mathrm{mg} / \mathrm{kg}$, diazepam $32 \mathrm{mg} / \mathrm{kg}$, diclofenac $8 \mathrm{mg} / \mathrm{kg}$, and a control group who not received any substance. For randomized distribution and allocation of groups, the simple randomization by raffle method was used. Each procedure with all mice during the experiment respected the principles and guidelines for researches in laboratory animals, cited in International Guiding Principles for Biomedical Research Involving Animal (1985). ${ }^{38}$

\section{Irwin Test in mice}

The test was conducted as an adaptation of the previously described, ${ }^{39,40}$ The substance was administered to mice in a double-blind manner. Subsequently, the animals were observed during a one hour in time ranges of 15, 30, 45 and $60 \mathrm{~min}$. The end points analyzed were presence or absence of the following: lethality, convulsions, straub tail, sedation, agitation, abnormal gait (rolling or toes), jumps, motor incoordination, piloerection, abdominal cramps, stereotypies (sniffing, chewing or head movements), head shaking, itching, and abnormal breathing. ${ }^{24,25}$

\section{Carrageenin-induced paw oedema in mice}

This was performed as previously indicated. ${ }^{41,42}$ The carrageenan $0.2 \%$ was injected subcutaneously into the mice plantar aponeurosis. The volume of the injected paw was measured before and after each injection with a LETICA digital plethysmometer (LE-750). Observations were made on 6 periods: pre-test (before the time of administration), 1, 2, 3, 4 and 5 hrs after administration. The inflammatory activity was calculated using the formula:

$$
\text { Oedema plantar }(\mathrm{ml})=\mathrm{Vt}-\mathrm{Vb}
$$

$\mathrm{Vt}=$ volume of the foot at measurement point.

$\mathrm{Vb}=$ paw volume before carrageenan administration (pre-test)

\section{Measurement of the plantar temperature}

The skin temperature was measured using digital thermometer without contact NC 100, ASTME 1965; IEC 60601-1; IEC 60601-1-2 (EMC). The measurements were made periodically on pre-test (before the time of administration), 1, 2, 3, 4 and 5 hrs after administration.

\section{Statistical analysis-}

For quantitative variables the following statistics were applied: 1 tail ANOVA, Tukey and Pearson Correlation Coefficient tests. For qualitative variables, Fisher's statistic was applied. It was considered statistical significance for $\mathrm{p}<0.05$ value and a confidence interval of $95 \%$. It was used like informatics support Microsoft Office Excel 2013 and the Graph Pad Prism Software version 5.01.

\section{RESULTS}

\section{Irwin Test}

The ethanol extract of the seeds of J. curcas induced neurotoxicity effects during the first hour assessment. The mainly evidenced effects were sedation, stereotypies and Straub tail in groups at doses of 400, 600, 800 and $1000 \mathrm{mg} / \mathrm{kg}$ of $J$. curcas seeds (See Table 1).

\section{Carrageenan induced paw edema}

The direct correlation between increased paw edema and administration dose was evidenced. The experimental groups 400, 600, 800 and $1000 \mathrm{mg} / \mathrm{kg}$ of $J$. curcas seeds showed statistical difference versus control groups only during the fifth hour of evaluation. Moreover, the group $1000 \mathrm{mg} / \mathrm{kg}$ of $J$. curcas seeds presented an increasing of plantar edema during all hours of evaluation (See Table 2).

\section{Paw skin temperature}

In a dose-response profile, the experimental groups showed increased of the skin temperature in a positive way. Particularly, the group at doses of $1000 \mathrm{mg} / \mathrm{kg}$ presented the highest temperature throughout the evaluation (See Table 3).

\section{DISCUSIÓN}

The presence of stereotype and Straub tail, would mean a stimulant effect in the the central nervous system level, which may be due to a possible induction of the serotonergic, dopaminergic, and opioidergic systems. ${ }^{24}$ It is recognized the neurotoxicity and fatality affects by the secondary metabolites phorbol esters from the seeds of $J$. curcas ${ }^{43}$ in contrast, other studies in some varieties of this plant showed poor toxicity. ${ }^{45,46}$

Other secondary metabolites present in the seed of J. curcas are alkaloids, flavonoids, tannins and saponins among others, ${ }^{20-23}$ could be responsible for the effects observed in this study.

Considering the presence of stereotype and Straub tail, it is possible that the ethanolic extract of J. curcas seed have a lipophilic chemical constitution, which would make it possible to cross the blood-brain barrier, and therefore, it should alert the potential risk during pregnancy and others. In this study, doses of 400, 600, 800 and $1000 \mathrm{mg} / \mathrm{kg}$ of ethanol extract of J. curcas seeds showed throughout early hours of evaluation an inflammatory effect similar to control group. Contrary, a research showed an anti-inflammatory effect of methanol extract of J. curcas root at dose of 100 and $200 \mathrm{mg} / \mathrm{kg}$. ${ }^{48}$ Similar results were showed in other study with the alcohol extracts of root, stem and leaf, at doses of $200 \mathrm{mg} / \mathrm{kg}$ showed a decrease of edema, ${ }^{49}$ and with aqueous extract of J. curcas leaves at doses of $300 \mathrm{mg} / \mathrm{kg}$ reduced edema significantly. ${ }^{50}$

The contradictory inflammatory effects presented by the seeds of the J. curcas in front of the others parts of the plant might have explanation in the presence or absence of their secondary metabolites, inclusively in the concentration or others, ${ }^{28,47,51}$ these variables are need to study in future studies.

In addition, the outcomes of the skin temperature are according to the inflammation cascade produced by carrageenan ${ }^{26,28,47,52,54}$ and in this case it is possible that the ethanolic extract of J. curcas induced elevation of the skin temperature by release autacoids like serotonin or prostaglandins, nonetheless, which should be clarified in future studies 
Table 1: Effects of ethanol extract of Jatropha curcas seed on Irwin test in the first hour

\begin{tabular}{|c|c|c|c|c|c|c|c|}
\hline Groups & \multirow{2}{*}{ Control } & \multirow{2}{*}{ Caffeine } & \multirow{2}{*}{ Diazepam } & \multirow{2}{*}{$400 \mathrm{mg} / \mathrm{kg}$} & \multirow{2}{*}{$600 \mathrm{mg} / \mathrm{kg}$} & \multirow{2}{*}{$800 \mathrm{mg} / \mathrm{kg}$} & \multirow{2}{*}{$1000 \mathrm{mg} / \mathrm{kg}$} \\
\hline Behaviours & & & & & & & \\
\hline Lethality & NO & NO & NO & NO & NO & NO & NO \\
\hline Convulsions & NO & NO & NO & NO & NO & NO & $\mathrm{NO}$ \\
\hline Straub tail * & YES & NO & YES & YES & NO & NO & NO \\
\hline Sedation $\uparrow$ & NO & NO & YES & NO & NO & NO & NO \\
\hline Excitation & NO & NO & NO & NO & NO & NO & NO \\
\hline Abnormal gait & NO & NO & NO & NO & NO & NO & NO \\
\hline Jumps & NO & NO & NO & NO & NO & NO & NO \\
\hline Motor incoordination & NO & NO & NO & NO & NO & NO & NO \\
\hline Abdominal writhes & NO & NO & NO & NO & NO & NO & NO \\
\hline Piloerection & NO & NO & NO & NO & NO & NO & NO \\
\hline Stereotypies $\ddagger$ & YES & YES & YES & YES & YES & YES & YES \\
\hline Head twitches & NO & NO & NO & NO & NO & NO & NO \\
\hline Scratching & NO & NO & NO & NO & NO & NO & NO \\
\hline Increase of respiration & NO & NO & NO & NO & NO & NO & NO \\
\hline Decrease of respiration & NO & NO & NO & $\mathrm{NO}$ & NO & $\mathrm{NO}$ & $\mathrm{NO}$ \\
\hline
\end{tabular}

${ }^{*}$ Chi square, $\mathrm{p}<0.05,400 \mathrm{mg} / \mathrm{kg}$ vs. Diazepam and Control (45 min).

Chi square, $\mathrm{p}<0.05$, Diazepam vs. 400, 600, 800 and $1000 \mathrm{mg} / \mathrm{kg}$ (30 and 45min), vs. Control and Caffeine (30 min).

$\ddagger$ Chi square, $\mathrm{p}<0.05$, Diazepam vs. Control (15 min), vs. 400 and $600 \mathrm{mg} / \mathrm{kg}$ (15 and $30 \mathrm{~min})$, vs. Caffeine (30 min), vs. Control, $800 \mathrm{and} 1000 \mathrm{mg} / \mathrm{kg}$ (45 min).

Table 2: Effects of ethanol extract of Jatropha curcas seed on Carrageenan-induced paw edema

\begin{tabular}{cccccc}
\hline \multirow{2}{*}{ Experimental groups } & \multicolumn{5}{c}{ Increase of paw edema } \\
\cline { 2 - 6 } & $\mathbf{1}^{\text {st }} \mathbf{h}$ & $2^{\text {nd }} \mathbf{h}$ & $3^{\text {rd }} \mathbf{h}$ & $\mathbf{4}^{\text {th }} \mathbf{h}$ & $5^{\text {th }} \mathbf{h}$ \\
\cline { 2 - 6 } & Mean \pm SD & Mean \pm SD & Mean $\pm S D$ & Mean \pm SD & Mean \pm SD \\
\hline $400 \mathrm{mg} / \mathrm{kg}$ & $0.07 \pm 0.05$ & $0.04 \pm 0.03$ & $0.06 \pm 0.04$ & $0.08 \pm 0.06$ & $0.06 \pm 0.05$ \\
$600 \mathrm{mg} / \mathrm{kg}$ & $0.06 \pm 0.04$ & $0.06 \pm 0.05$ & $0.06 \pm 0.08$ & $0.06 \pm 0.04$ & $0.06 \pm 0.07$ \\
$800 \mathrm{mg} / \mathrm{kg}$ & $0.06 \pm 0.05$ & $0.03 \pm 0.03$ & $0.06 \pm 0.05$ & $0.07 \pm 0.06$ & $0.04 \pm 0.05$ \\
$1000 \mathrm{mg} / \mathrm{kg}$ & $0.08 \pm 0.05$ & $0.09 \pm 0.04$ & $0.09 \pm 0.05$ & $0.11 \pm 0.08$ & $0.14 \pm 0.08$ \\
Diclofenac & $0.04 \pm 0.05$ & $0.05 \pm 0.05$ & $0.05 \pm 0.06$ & $0.05 \pm 0.04$ & $0.06 \pm 0.03$ \\
Control & $0.07 \pm 0.07$ & $0.03 \pm 0.06$ & $0.06 \pm 0.05$ & $0.06 \pm 0.06$ & $0.11 \pm 0.04$ \\
\hline
\end{tabular}

* ANOVA, p<0,05; Tukey, p<0,05; $1000 \mathrm{mg} / \mathrm{kg}$ vs. Control, Diclofenac, 400, 600 and $800 \mathrm{mg} / \mathrm{kg}$.

SD: Standard Deviation.

Table 3: Effects of ethanol extract of Jatropha curcas seed on paw skin temperature*

\begin{tabular}{ccccccc}
\hline \multirow{2}{*}{ Experimental groups } & Basal & $1^{\text {st }} \mathbf{h}$ & $2^{\text {nd }} \mathbf{h}$ & $3^{\text {rd }} \mathbf{h}$ & $4^{\text {th }} \mathbf{h}$ & $5^{\text {th }} \mathbf{h}$ \\
\cline { 2 - 7 } & Mean \pm SD & Mean \pm SD & Mean \pm SD & Mean \pm SD & Mean \pm SD & Mean \pm SD \\
\hline $400 \mathrm{mg} / \mathrm{kg}$ & $26.89 \pm 3.59$ & $29.36 \pm 1.10$ & $29.75 \pm 2.23$ & $28.39 \pm 1.85$ & $29.50 \pm 1.34$ & $30.08 \pm 1.65$ \\
$600 \mathrm{mg} / \mathrm{kg}$ & $29.09 \pm 2.88$ & $29.83 \pm 1.96$ & $29.84 \pm 1.60$ & $30.68 \pm 2.05$ & $30.61 \pm 2.45$ & $30.56 \pm 2.00$ \\
$800 \mathrm{mg} / \mathrm{kg}$ & $28.96 \pm 1.35$ & $29.66 \pm 1.84$ & $29.49 \pm 2.38$ & $30.75 \pm 3.09$ & $31.73 \pm 0.71$ & $31.25 \pm 1.83$ \\
$1000 \mathrm{mg} / \mathrm{kg}$ & $28.00 \pm 2.27$ & $30.75 \pm 2.21$ & $30.70 \pm 1.57$ & $31.23 \pm 1.08$ & $30.61 \pm 1.39$ & $31.33 \pm 1.40$ \\
Diclofenac & $28.88 \pm 1.17$ & $30.36 \pm 1.44$ & $29.99 \pm 1.79$ & $30.36 \pm 0.98$ & $29.18 \pm 2.29$ & $30.04 \pm 1.92$ \\
Control & $28.96 \pm 2.98$ & $29.83 \pm 1.96$ & $30.03 \pm 1.75$ & $30.94 \pm 1.69$ & $30.06 \pm 2.51$ & $29.70 \pm 2.16$ \\
\hline
\end{tabular}

*ANOVA, $>0.05$; Pearson correlation $\mathrm{p}<0.05, \mathrm{r}=0.04269$

SD: Standard Deviation. 


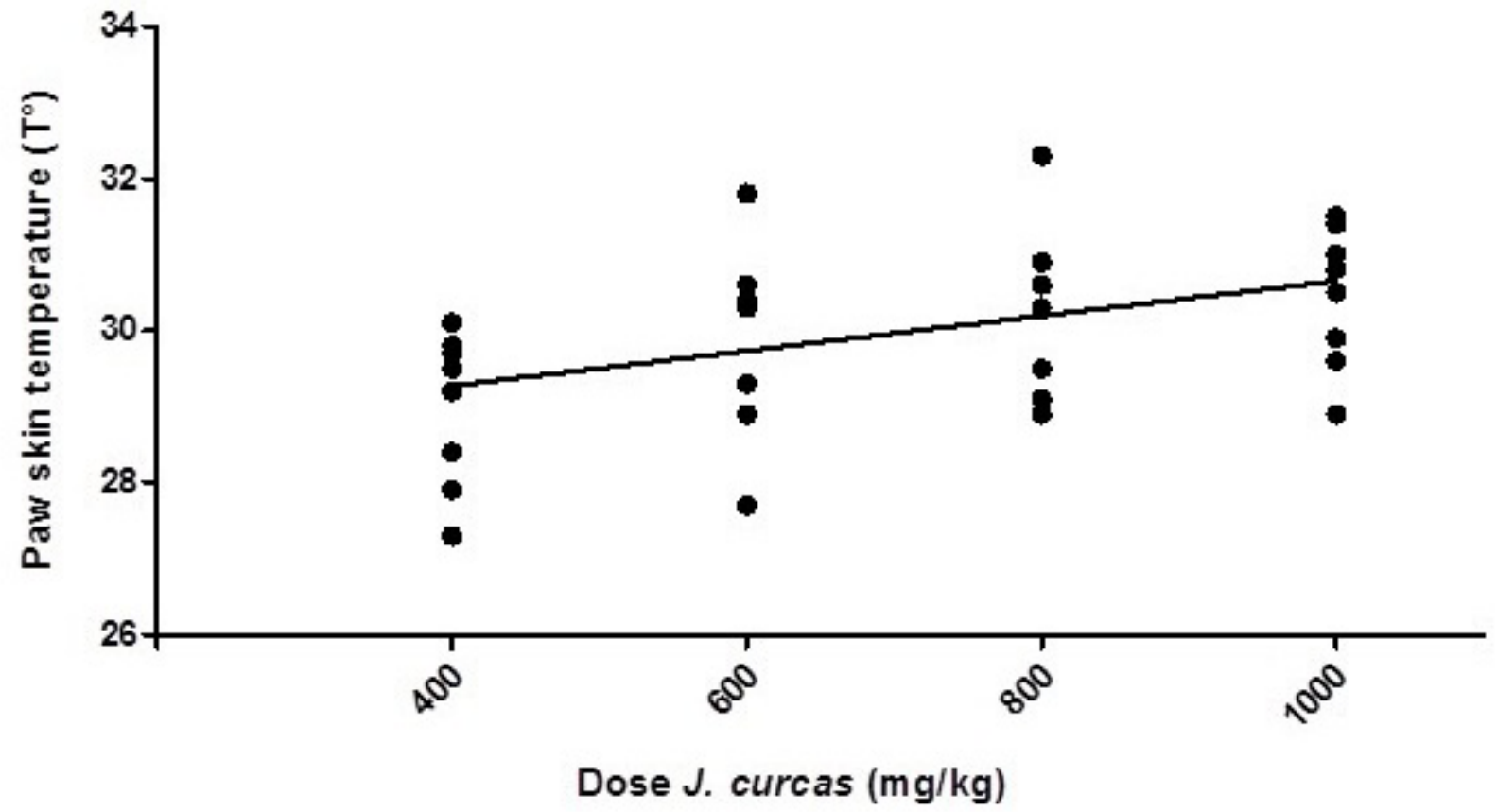

Figure 1: Correlation between dose of J. curcas and paw skin temperature.

\section{CONCLUSION}

The ethanolic extract of the seed of J. curcas presented inflammatory activity and central nervous system activity like stereotype and Straub tail profile.

\section{AUTHORS' CONTRIBUTIONS}

Author contributions to the study and manuscript preparation are as follows: ZHA, ZHR, GLS, and SGA conceived and designed the study. ZHA, ZHR, GLS, ZFE, GBJ, CSA and PMC performed the experiment. ZHA, ZHR, GLS, ZFE and PMC acquired of data. ZHA, ZHR, and GLS developed statistical analysis. All authors analysed and contributed to data interpretation. SGA drafted the manuscript. All authors revised and approved the final manuscript.

\section{ACKNOWLEDGMENTS}

This research was supported by the authors and FMH-USMP. We would like to express our appreciation and gratefulness to Frank Lizaraso Caparo M.D. (Dean of the FMH-USMP), Benjamin Castañeda Castañeda M.D. (Past former director and researcher of the Institute of research of the FMH-USMP), Angel Alvarado Yarasca, Berta Loja Herrera (professors and researchers of Research Centre of Traditional Medicine and Pharmacology of FMH-USMP), Yordan Martinez Espichan, Gabriela Gonzales Pariona and Jonathan Troncoso Zuñiga (medical students of FMH-USMP) for their collaborations.

\section{CONFLICT OF INTEREST}

The authors declare that they have no conflict of interests.

\section{ABBREVIATION USED}

None.

\section{REFERENCES}

1. Kumar A, Sharma S. An evaluation of multipurpose oil seed crop for industrial uses (Jatropha curcas L.): A review. Ind Crops Prod. 2008;28(1):1-10.

2. Prasad DMR. Jatropha curcas: Plant of medical benefits. J Med Plants Res. 2012;6(14):2691-9.

3. Sabandar CW, Ahmat N, Jaafar FM, Sahidin I. Medicinal property, phytochemistry and pharmacology of several Jatropha species (Euphorbiaceae): A review. Phytochemistry. 2013;85:7-29.

4. Abdulla R, Chan ES, Ravindra P. Biodiesel production from Jatropha curcas: a critical review. Crit Rev Biotechnol. 2011;31(1):53-64.

5. Khafagy SM, Mohamed YA, Abdel-Salam NA, Mahmoud ZF. Phytochemical study of Jatropha curcas. Planta Med. 1977;31(3):273-7.

6. Osoniyi O, Onajobi F. Coagulant and anticoagulant activities in Jatropha curcas latex. J Ethnopharmacol. 2003;89(1):101-5.

7. López Sáez JA, Pérez Soto J. Potencial etnomedicinal de dos especies tropicales del género Jatropha L. Med Natur. 2011;5(1):8-12.

8. Pinedo MP. Plantas medicinales de la amazonia peruana: estudio de su uso y cultivo. Iquitos: Instituto de Investigaciones de la Amazonía Peruana; 1997. $304 \mathrm{p}$.

9. Carrasco RJM, Fartolino GA, Sánchez CÁ, Lujan RJ, Pachas QA, Castilla CLDC. Efecto sobre la motilidad intestinal del extracto de alcaloides de semilla de Jatropha curcas L. Rev Cuba Plantas Med. 2013;18(1):84-91.

10. Chivandi E, Erlwanger KH, Makuza SM, Read JS, Mtimuni JP. Effects of dietary Jatropha curcas meal on percent packed cell volume, serum glucose, cholesterol and triglyceride concentration and alpha-amylase activity of weaned fattening pigs. Res J Anim Vet Sci. 2006;1(1):18-24.

11. Saetae D, SuntornsukW. Antifungal activities of ethanolic extract from Jatropha curcas seed cake. J Microbiol Biotechnol. 2010;20(2):319-24.

12. Ratnadass A, Wink M. The Phorbol Ester Fraction from Jatropha curcas Seed Oil: Potential and Limits for Crop Protection against Insect Pests. Int J Mol Sci. 2012;13(12):16157-71.

13. Makonnen E, Rostom AA, Assefa G, Zerihun L. Antifertility effect of Jatropha Curcas L. seed in guinea pigs. Ethiop J Health Dev. 1997;11(2):145-8.

14. Igbinosa OO, Igbinosa EO, Aiyegoro OA. Antimicrobial activity and phytochemical screening of stem bark extracts from Jatropha curcas (Linn). Afr J Pharm Pharmacol. 2009;3(2):58-62.

15. Mujumdar AM, Misar AV, Salaskar MV, Upadhye AS. Antidiarrhoeal Effect of Isolated Fraction (JC) of Jatropha curcas Roots in Mice. J Nat Remedies. $2001 ; 1(2): 89-93$.

16. Shetty S, Udupa SL, Udupa AL, Vollala VR. Wound healing activities of Bark Extract of Jatropha curcas Linn in albino rats. Saudi Med J. 2006;27(10):1473-6.

17. Mujumdar AM, Misar AV. Anti-inflammatory activity of Jatropha curcas roots in mice and rats. J Ethnopharmacol. 2004;90(1):11-5. 
18. Goonasekera MM, Gunawardana VK, Jayasena K, Mohammed SG, Balasubramaniam S. Pregnancy terminating effect of Jatropha curcas in rats. J Ethnopharmacol. 1995;47(3):117-23

19. Uche Fl, Aprioku JS. The Phytochemical Constituents, Analgesic and Antiinflammatory effects of methanol extract of Jatropha curcas leaves in Mice and Wister albino rats. J Appl Sci Environ Manag. 2008;12(4):99-102.

20. Nwokocha BA, Agbagwa IO, Okoli BE. Comparative Phytochemical Screening of Jatropha L. Species in the Niger Delta. Res J Phytochem. 2011;5(2):107-14.

21. Verma S, Gupta A, Kushwaha P, Khare V, Srivastava S, Rawat AKS. Phytochemical Evaluation and Antioxidant Study of Jatropha curcas Seeds. Pharmacogn J. 2012;4(29):50-4.

22. Abdelgadir HA, Van Staden J. Ethnobotany, ethnopharmacology and toxicity of Jatropha curcas L. (Euphorbiaceae): A review. South Afr J Bot. 2013;88(1):204-18.

23. Ugbogu AE, Akubugwo El, Uhegbu El, Chinyere FO, Ugbogu OC, Oduse KA. Nutritional and chemical composition of Jatropha curcas (L) seed oil from Nigeria. Int J Biosci IJB. 2013;3(8):125-34.

24. Roux S, Sablé E, Porsolt RD. Primary Observation (Irwin) Test in Rodents for Assessing Acute Toxicity of a Test Agent and its Effects on Behavior and Physiological Function. In: Enna SJ, Williams M, Barret JF, Ferkany JW, Kenakin T, Porsolt RD, editors. Current Protocols in Pharmacology. Hoboken, NJ, USA: John Wiley and Sons, Inc.; 2005.

25. Vogel HG. Psychotropic and neurotropic activity. In: Vogel HG, Huger FP, editors. Drug Discovery and Evaluation: Pharmacological Assays. New York: Springer Science and Business Media; 2013. p. 204-5.

26. Whiteley PE, Dalrymple SA. Models of Inflammation: CarrageenanInduced Paw Edema in the Rat. In: Current Protocols in Pharmacology. Hoboken, NJ, USA: John Wiley and Sons, Inc.; 2001

27. Vogel HG. Analgesic, Anti-inflammatory, Anti-pyretic activity. In: Schleyerbach R, Weithmann KU, Bartlett RR, editors. Drug Discovery and Evaluation: Pharmacological Assays. New York: Springer Science and Business Media; 2013. p. 406-8.

28. Winyard PG, Willoughby DA. Carrageenan-induced paw edema in the rat and mouse. In: Morris CJ, editor. Inflammation Protocols. Bath, UK: Springer; 2003. p. 115-21.

29. Pabón LC, Hernández-Rodríguez P. Importancia química de Jatropha curcas y sus aplicaciones biológicas, farmacológicas e industriales. Rev Cuba Plantas Med. 2012;17(2):194-209.

30. Cerrate E. Manera de preparar plantas para un herbario. Lima: Museo de Historia Natural, Universidad Nacional Mayor de San Marcos; 1969.

31. Brako L, Zarucchi JL. Catalogue of the Flowering Plants And Gymnosperms of Peru. St. Louis, Mo: Missouri Botanical Garden; 1993. 1286 p.

32. Wu Z, Raven PH, Garden MB. Euphorbiaceae. In: Bingtao L, Gilbert MG, editors. Flora of China. Chicago: Science Press; 1995. p. 268-9.

33. Brako L, Rossman AY, Farr DF. Scientific and Common Names of 7,000 Vascular Plants in the United States. St. Louis, Mo: APS Press; 1995. 295 p.

34. Dehgan B. Jatropha (Euphorbiaceae). New York: Organization for Flora Neotropica; 2012. 273 p.

35. Germishuizen G, Meyer NL, National Botanical Institute (South Africa), editors Plants of southern Africa: an annotated checklist. Pretoria: National Botanical Institute; 2003. 1231 p.

36. Hammel BE. Euphorbiaceae. In: González-Ramírez J, editor. Manual de plantas de Costa Rica. St. Louis, Mo: Missouri Botanical Garden Press; 2010. p. 290-394.
37. Wu Z, Raven PH, Garden MB. Flora of China. Chicago: Science Press; 1995. $648 \mathrm{p}$.

38. Institute for Laboratory Animal Research (U.S.), editor. Appendix D: International Guiding Principles for Biomedical Research Involving Animals (1985). In: The development of science-based guidelines for laboratory animal care: proceedings of the November 2003 international workshop. Washington, D.C: National Academies Press; 2004. p. 240-8.

39. Irwin S. Drug screening and evaluation of new compounds in animals. Anim Clin Pharmacol Tech Drug Eval. 1964;36-54.

40. Irwin S. Comprehensive observational assessment: la. A systematic, quantitative procedure for assessing the behavioral and physiologic state of the mouse. Psychopharmacologia. 1968;13(3):222-57.

41. Winter CA, Risley EA, Nuss GW. Carrageenin-induced edema in hind paw of the rat as an assay for antiiflammatory drugs. Proc Soc Exp Biol Med Soc Exp Biol Med NY N. 1962;111(3):544-7.

42. Levy L. Carrageenan paw edema in the mouse. Life Sci. 1969;8(11, Part 1):601-6.

43. Wakandigara A, Nhamo LRM, Kugara J. Chemistry of Phorbol Ester Toxicity in Jatropha curcas Seed-a Review. Int J Biochem Res Rev. 2013;3(3):146-61.

44. Makkar HPS, Becker K. Jatropha curcas toxicity: identification of toxic principle(s). In: Garland T, Barr AC, editors. Toxic plants and other natural toxicants. CAB International. Wallingford UK: CAB International; 1998. p. 554-8.

45. Valdes-Rodriguez OA, Sanchez-Sanchez O, Perez-Vazquez A, Caplan J. The Mexican Non-toxic Jatropha curcas L., Food Resource or Biofuel? Ethnobot Res Appl. 2013;11:1-7.

46. Herrera JM, Martinez CJ, Vera NG. Use of Jatropha curcas L. (Non-Toxic Variety) as Traditional Food and Generation of New Products in Mexico. In: Carels N, Sujatha M, Bahadur B, editors. Jatropha, Challenges for a New Energy Crop. Springer Science and Business Media. New York: Springer New York; 2012. p. 333-41.

47. Di Rosa M, Giroud JP, Willoughby DA. Studies of the mediators of the acute inflammatory response induced in rats in different sites by carrageenan and turpentine. J Pathol. 1971;104(1):15-29.

48. Olukunle JO, Adenubi OT, Oladele GM, Sogebi EA, Oguntoke PC. Studies on the anti-inflammatory and analgesic properties of Jatropha curcas leaf extract. Acta Vet Brno. 2011;80(3):259-62.

49. Nayak BS, Patel KN. Anti-inflammatory screening of Jatropha curcas root, stem and leaf in albino rats. Rom J Biol Plant Biol. 2010;55(1):9-13.

50. Sangeetha J, Divya K, Vamsikrishna MPA, Rani GL. Anti-inflammatory and antibacterial activity of Jatropha Curcas Linn. Asian J Pharm Res Health Care. 2010;2(3):258-62.

51. Goel G, Makkar HPS, Francis G, Becker K. Phorbol Esters: Structure, Biological Activity, and Toxicity in Animals. Int J Toxicol. 2007;26(4):279-88.

52. Medzhitov R. Origin and physiological roles of inflammation. Nature 2008;454(7203):428-35

53. Stables MJ, Gilroy DW. Old and new generation lipid mediators in acute inflam mation and resolution. Prog Lipid Res. 2011;50(1):35-51.

54. Vinegar R, Truax Jf, Selph JI, Johnston Pr, Venable Al, McKenzie Kk. Pathway to carrageenan-induced inflammation in the hind limb of the rat. Fed Proc. 1987;46(1):118-26

\section{PICTORIAL ABSTRACT}

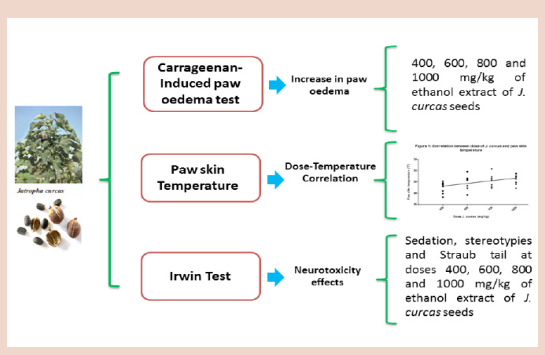

\section{SUMMARY}

- The ethanol extract of $J$. curcas seeds were showed effects on inflammation and the nervous system

- The ethanol extract of J. curcas seeds showed an inflammatory effect, effects on the nervous system were founded as stereotypes and Straub tail through Irwin test. 


\section{ABOUT AUTHORS}

Alexander Zambrano Huailla: Is a Junior Researcher and student currently at 7th year of Medical School at Universidad de San Martin de Porres. He is member of the SOCIEDAD CIENTIFICA DE ESTUDIANTES DE MEDICINA HUMANA (SOCIEMUSMP), which's main goal is to promote research. His clinical practices are at Hospital Jorge VotoBernales C. His research interests include the pharmacological effects of the Peruvian medicinal plants, especially central nervous system, in order to improve existing information about the plants of common use in communities. He is also interested in neurology, and hopes to keep developing researches in the following years of her medical education.

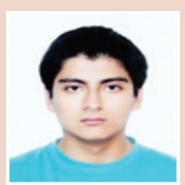

Rommel Zambrano Huailla: Is a Junior Researcher and student currently at 7th year of Medical School at Universidad de San Martin de Porres. He is member of the SOCIEDAD CIENTIFICA DE ESTUDIANTES DE MEDICINA HUMANA (SOCIEMUSMP), which's main goal is to promote research. His clinical practices are at Hospital Nacional Guillermo Almenaralrigoyen. His research interests include the pharmacological effects of the Peruvian medicinal plants, especially cardiologic system, in order to improve existing information about the plants of common use in communities. He is also interested in cardiology, and hopes to keep developing researches in the following years of her medical education.

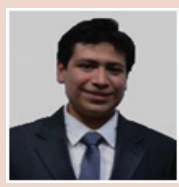

DE MEDICINA HUMANA (SOCIEM-USMP): Which's main goal is to promote research. His clinical practices are at Hospital Nacional Guillermo Almenaralrigoyen. His research interests include the pharmacological effects of the Peruvian medicinal Sergio Goicochea Lugo: Is a Junior Researcher and student currently at 7th year of Medical School at Universidad de San Martin de Porres. He is member of the SOCIEDAD CIENTIFICA DE ESTUDIANTES plants, especially central nervous system, in order to improve existing information about the plants of common use in communities. He is also interested in Internal Medicine, and hopes to keep developing researches in the following years of his medical education.

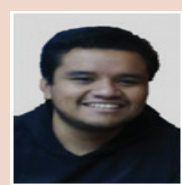

Ernesto Zavala Flores: Is a Junior Researcher and student currently at 7th year of Medical School at Universidad de San Martin de Porres. He is member of the SOCIEDAD CIENTIFICA DE ESTUDIANTES DE ME-DICINA HUMANA (SOCIEM-USMP), which's main goal is to promote research. His clinical practices are at Hospital Aurelio DíazUfano. His research interests include the pharmacological effects of the Peruvian medicinal plants, especially central nervous system, in order to improve existing information about the plants of common use in communities. Heis also interested in Rheumatology, and hopes to keep developing researches in the following years of his medical education.

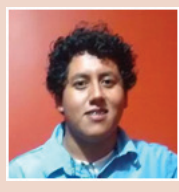

Jorge García Berrocal: Is a Junior Researcher and student currently at 7th year of Medical School at Universidad de San Martin de Porres. He is member of the SOCIEDAD CIENTIFICA DE ESTUDIANTES DE ME-DICINA HUMANA (SOCIEMUSMP), which's main goal is to promote research. His clinical practices are at Hospital Nacional Maria Auxiliadora. His research interests include the pharmacological effects of the Peruvian medicinal plants, especially central nervous system, in order to improve existing information about the plants of common use in communities. He is also interested in Traumatology, and hopes to keep developing researches in the following years of her medical education.

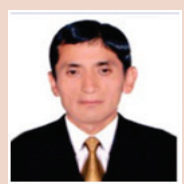

Angel Chau Saravia: Is a Junior Researcher and student currently at 7th year of Medical School at Universidad de San Martin de Porres. Her clinical practices are at Hospital Nacional ArzobispoLoayza. His research interests include the pharmacological effects of the Peruvian medicinal plants, especially central nervous system, in order to improve existing information about the plants of common use in communities. He is also interested in Gastroenterology, and hopes to keep developing researches in the following years of her medical education.

Carlos Pante Medina: Is a laboratory technician at the Centro de Investigación de MedicinaTradicional y Farmacología of the Facultad de Medicina Humana de la Universidad de San Martin de Porres, Lima, Peru. He is specialized in animal experimentation.

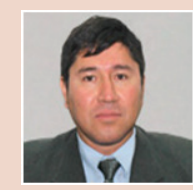

Alberto Salazar Granara: Is a Professor in Pharmacology and Researcher at the Centro de Investigación de MedicinaTradicional y Farmacología of the Facultad de Medicina Humana de la Universidad de San Martin de Porres, Lima, Peru. His research interests are the pharmacological effects of the Peruvian medicinal plants, especially central nervous system effects, anti-inflammatory and analgesic properties. He is also interested in discover off-label effect from the common antihypertensive, antidiabetic,antidepressants and analgesic drugs. He is also interested in exploring the pharmacogenetic and pharmacokinetic highlight markers in Peruvian population, applied in important pathologies like Peruvian tuberculosis, hypertension, diabetes and others. 